\title{
HYPERTENSION INFORMATION CAMPAIGN COMMUNITY-BASED INTERVENTION DESIGN ON STUDENTS'S KNOWLEDGE AND ATTITUDE IMPROVEMENT OF HYPERTENSION POTENCY
}

\author{
Zulmi Ramdani \\ S.Psi (Bachelor of Psychology), Master Candidate on Psychometrics in Gadjah Mada University- \\ Yogyakarta, Indonesia, zulmiramdani94@gmail.com
}

\begin{abstract}
Ministry of Health of the Republic of Indonesia in 2013 published data of the number of hypertensive patients in Indonesia which reached $25.8 \%$ of the total population. It means that about 100 million people aged 18 years and over are in a hypertensive condition. Hypertension is a non-spreading disease that causes a person to experience an imbalance of life control and management that results in other severe diseases such as kidney failure, coronary heart disease, and the human nervous system damage (Bozorgmanesh et al, 2014). One factor that causes a person susceptible to this disease is psychological symptoms. Psychological factors are sometimes not easily known and anticipated so that people's awareness is needed to anticipate them. Community-based intervention is very effective in changing subject's attitude, knowledge, and behavior to be better (Torlasco et al., 2017). This intervention program is conducted primarily when it aims to provide information on the psychological symptoms developed by a person affected by hypertension. Based on a preliminary study of 50 random subjects in the Psychology Faculty of UGM, the results show that there is a tendency of students being affected by hypertension due to psychological factors. This is derived from the small scores on the scale of The Health-Promoting Lifestyle (HPLP) and The Management Strategic Scale (MSS). Psychological factors that should be concerned are stress management, self-regulation and emotion, and also personality attributes.
\end{abstract}

Keywords: Hypertension, Information Campaign, Psychological Symptoms

\section{INTRODUCTION}

Hypertension or better known as high blood pressure disorder is one of the many diseases suffered by the Indonesian society today. Based on data published by the Ministry of Health of the Republic of Indonesia in 2013 , the number of hypertensive patients aged more than 18 years in Indonesia reached $25.8 \%$ of the total 
population (Kementrian Kesehatan, 2013). This figure indicates that about 100 million of Indonesia's population aged 18 years are in a condition of hypertension. Although this number has decreased compared to 2007 which reached $31.7 \%$, the number of patients for hypertensive disorders is included in the number of most compared with other non-infectious diseases such as Heart, Cancer, and Diabetes.

Judging by sex, there is no fundamental difference in the prevalence between men and women in people with hypertension (Martinovic, Belojevic, Evans, Kavaric, \& Asanin, 2017). Other data shown by Roger et al (2011) mention that in every minute one woman dies of Cardiovascular disorders (including hypertension), especially in the majority of developing countries (Gudmundsdottir, Høieggen, Stenehjem, Waldum, \& Os, 2012).

Patients with hypertension experience have a situation with unbalanced blood pressure in the body, where blood pressure in blood vessels increases chronically. It can happen because the heart works harder to pump blood to meet the needs of oxygen and nutrients the body. So that will happen is the imbalance with control and management on the lives of individuals who also interact directly with other diseases such as stroke, kidney failure, coronary heart disease, and even could have happened damage to the human nervous system (Artinian, 2004) in (Bozorgmanesh, Ghoreishian, Mohebi, Azizi, \& Hadaegh, 2014).

Hypertension is a type of non-communicable disease that is not only caused by biological factors such as previous medical history of the patient (Terre, 2009), the content of metal in the patient's body (Garner \& Levallois, 2017), and age of the patient (Torlasco et al., 2017), but also factors such as living environment and lifestyle also have a major effect on the emergence of this disease. Environmental factors that affect the vulnerability of a person affected by hypertension is the intensity and exposure of air around it (Garner \& Levallois, 2017). People living in urban areas will be prone to hypertension due to factors of distress and access to indiscriminate lifestyles such as fast food consumption are also prone to hypertension (Perez, 2011).

Psychological factors have been clearly mentioned as non-physical factors that can cause a person affected by hypertension, one of which is the stress management that is owned by the individual (Kementrian Kesehatan, 2013). Medically a person's blood pressure will become uncontrollable when confronted with stressful situations that individuals can not face (Canada et al., 2017). These pressures can be conflicts with friends or their own family (Terre, 2009). The pressure can be problematic when the individual is unable to control the self-regulation they have. Self-regulation will help the individual to see the activity of stress as a thing to be controlled (Leventhal, 2006).

Hypertension can also occur due to individual personality factors. One is the individual's attitude to the symptoms he experienced (Cheng, Montgomery, Treglown, \& Furnham, 2016), As well as the specific trait it has. Extraversion personality requires a lot of fun and stimulus that directs lifestyle on increasing hypertension. In contrast to the more empathic agreeableness personality it is less likely to develop hypertension because they are less likely to avoid conflict (Cheng et al., 2016). Individuals who are members of a religious community tend to have an immune system and a balanced blood pressure level (Terre, 2009). This does not occur in individuals who often experience loneliness that tend to be inactive and difficult to care for their own body health.

\section{HYPERTENSION PROBLEM TREE}

Descriptions and analysis of factors that may affect the occurrence of hypertensive disease in individuals will be illustrated in the problem tree below. 


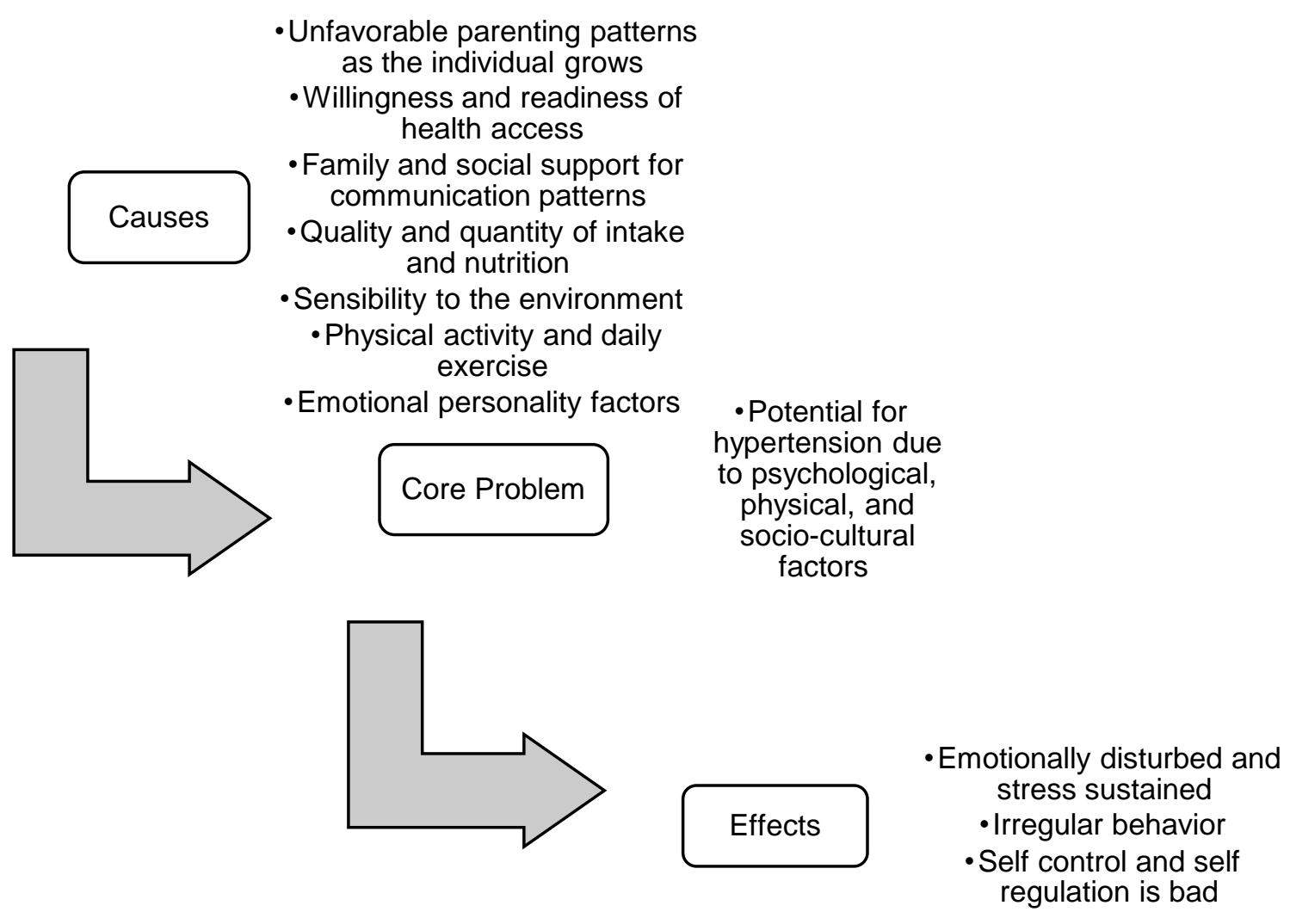

Fig 1. Problem Tree

\section{EXPERIMENTAL DESIGN}

To see to what extent the developed intervention has a significant effect on the subjects' behavior on hypertension symptoms, the design the researcher will conduct is a quasi-experimental study. The first has to do is an observational and descriptive study on a group that may provide a better understanding of the process or target that we will change and make a tentative conclusion (Grimshaw, Campbell, Eccles, \& Steen, 2000). The design to be used is randomized one group pretest-posttest design. This selection is based on the type of community-based intervention that the subject is already established, the researcher is little in control, and whether there is a change in attitude or behavior of subjects after being given treatment in the form of hypertension intervention described previously.

Aspects that will be indicators of measurement of the subject is the attitude and knowledge of hypertension disease. The initial assumption that there are differences in attitude and knowledge of the subject about hypertension before and after treatment is given. The subject chosen by the criteria is a UGM graduate students of psychology who is in the community.

$H_{0}: D=0$, The average score the subject gets when pretest and posttest are the same / does not differ significantly.

$H_{1}: D \neq 0$, The average score the subject earns when pretest and posttest is significantly different.

The measuring tools to be used in this experimental design are two attitudinal scales that have been adapted from two scales on attitudes toward health especially related to hypertensive disorder. The first is The Health-Promoting Lifestyle Profile (HPLP) developed by Walker (1987) which contains 6 dimensions of self-actualization, health responsibility, exercise, nutrition, interpersonal support, and stress management. The scale is based on analysis of hypertension problems (Park, 1990) containing 37 disclosed statements with answers ranging from never (1), sometimes (2), often (3), and always (4) (Riffle, Ph, Yoho, Sams, \& Ph, 1989). While the second scale is The Management Strategies Scale (MSS) developed by Wiliams regarding the attitudes and trends of people to behave healthy. MSS scale has two dimensions of self care / self reflection and cognitive / relaxation techniques that contains 11 items and filled with a score of 1-5 that 
shows how often subjects do the statement (Williams, Hurley, Brien, Gregorio, \& Mary, 2003). Scores obtained before and after subjects are given treatment will be compared and viewed the difference. By using paired sample test, because the sample used is a sample from one same group and has been treated equally (Santosa, 2015).

\section{RESULTS OF INITIAL STUDY}

Initial research was conducted on 50 students who are in faculty of psychology UGM. The study was conducted by identifying whether there is a tendency of hypertension experienced by the students seen from the potential or psychological symptoms that they face.

Table 1. Description of Scale (Blue Prints)

\begin{tabular}{|c|c|c|r|c|c|}
\hline \multicolumn{3}{|c|}{$\begin{array}{c}\text { Scale 1. The Health-Promoting Lifestyle } \\
\text { Profile (HPLP) }\end{array}$} & \multicolumn{3}{c|}{ Scale 2. The Management Strategies Scale (MSS) } \\
\hline No & Aspects & Total & No & Aspects & Total \\
\hline 1 & Self-Actualization & 8 items & 1 & Self-Care/Self Reflection & 6 items \\
\hline 2 & Health Responsibility & 8 items & 2 & Cognitive/Relaxation Techniques & 5 items \\
\hline 3 & Exercise & 3 items & & & \\
\hline 4 & Nutrition & 6 items & & & \\
\hline 5 & Interpersonal Support & 5 items & & & \\
\hline 6 & Stress Management & 7 items & & & Total \\
\hline \multicolumn{7}{|c|}{ Total } & 37 items & & & \\
\hline
\end{tabular}

Data were taken using both of the above scales taking into account the existing samples. Below are the results of the description analysis by using SPSS which shows how the potential of hypertension that occurs in the sample concerned. The reliability score above shows that the scale used has good reliability or consistency.

Table 2. Reliability Coefficients of Scales

\begin{tabular}{|c|c|c|}
\hline Scale & Items & Reliability Coefficients \\
\hline I & 37 & 0.816 \\
\hline II & 11 & 0.770 \\
\hline
\end{tabular}

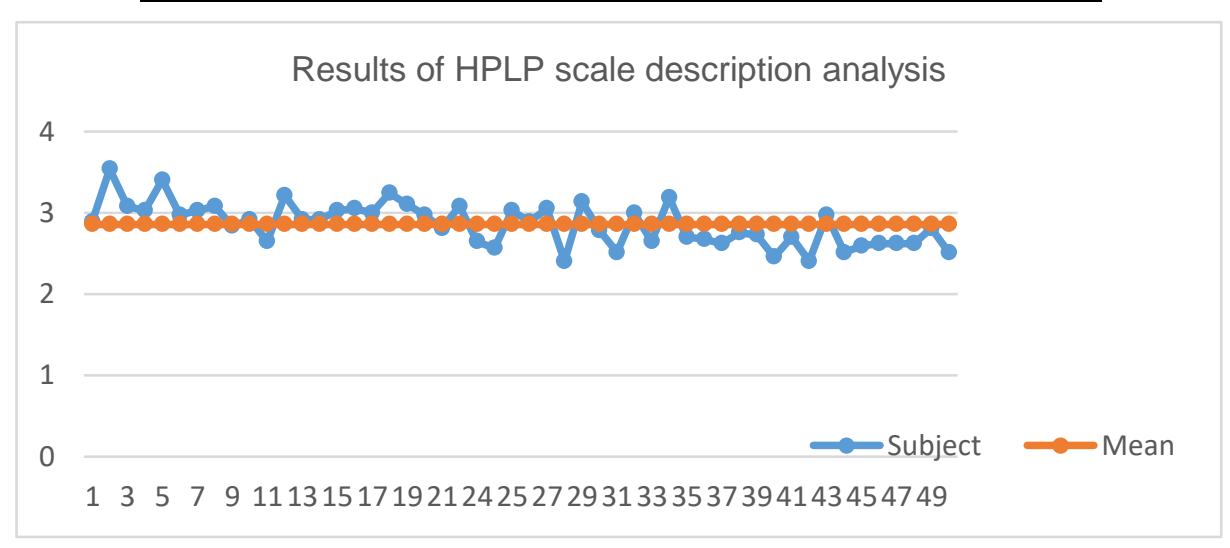

Fig 2. Results of HPLP Scores 


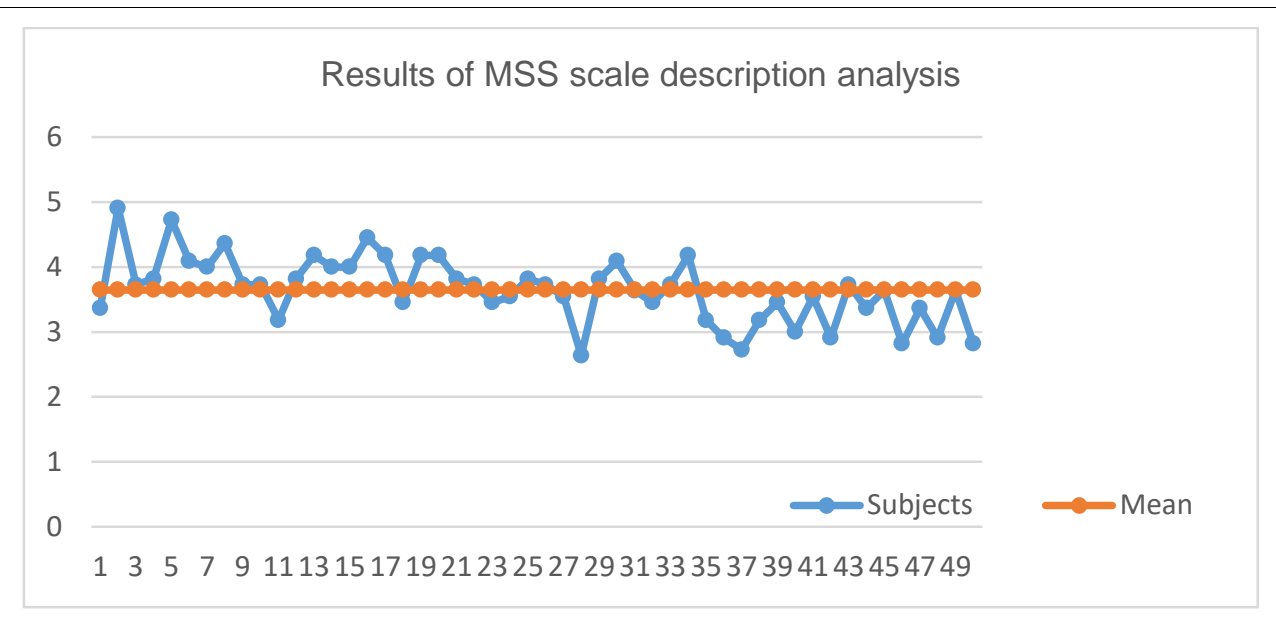

Fig 3. Results of MSS Scores

Both images above show that the results obtained through the first scale and second scale provide information related to the symptoms of hypertension that can be experienced by the subjects. This is seen from the number of subjects who score below the group average and also the low total gain on both scales above. So with such results psychological symptoms that can cause a person affected by hypertension must be known clearly.

\section{PURPOSE AND TARGET OF INTERVENTION}

The various factors mentioned earlier indicate that a person's chances of developing hypertension are heavily influenced by the psychological aspect. The form of pain experienced by individuals because of psychological factors is also not easy to realize directly by the concerned. So it is important to understand in advance that the disease is not always sick and the body's body was not due to physical or environmental factors alone, in this case the psychological factors into things to be detected quickly by themselves.

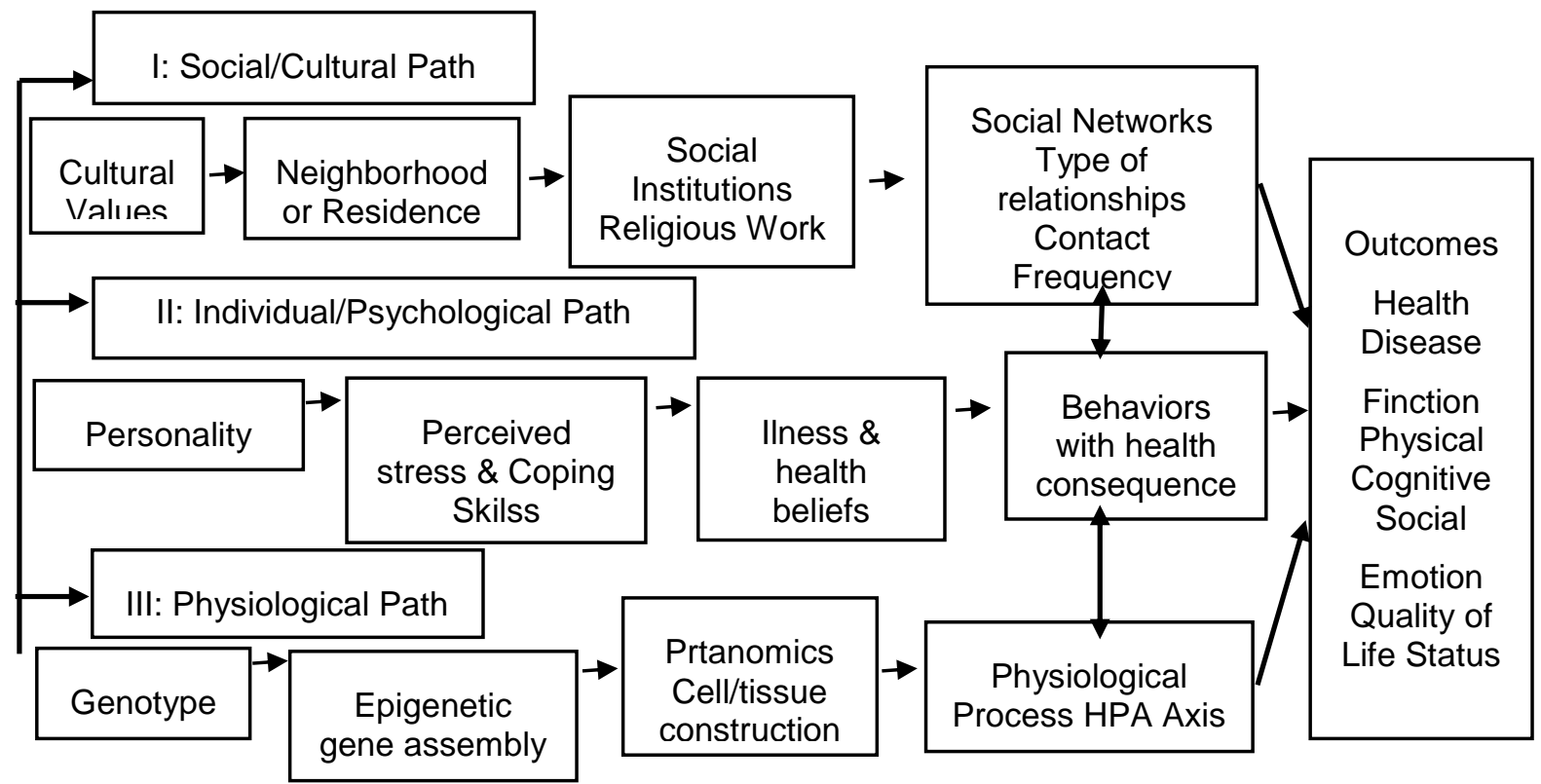

(Fig 4. Connection / Pathway For Studying Health \& Behavior, taken in (Leventhal, 2006))

The illustration above illustrates that in studying the relationship between health and human behavior, there are three things that must be considered in determining the reason the person's behavior can occur. Health disorders experienced by individuals in this case is hypertension occurs due to various aspects, namely social, cultural, psychological or individual individuals, as well as physiological aspects. These three aspects will determine the healthy criteria for improving the quality and happiness of the individual in the future. 
Based on the illustration and problem analysis in the previous discussion, the focus of the object in this study are students of the Faculty of Psychology, University of Gadjah Mada Yogyakarta. Geographically Yogyakarta became one of the areas with the highest hypertension potential in Indonesia, with prevalence reaching 12.8\% -12.9\% (Kementrian Kesehatan, 2013) And supported by data on high population density and distress. The number of people who occupy Yogyakarta per-kilometer reaches 1,174 people and occupies the position of the fourth solid area in Indonesia (Kesehatan, 2015). Students are also progressively at the age of the risk of hypertension and various problems that will be faced with regard to lectures and personal life activities (Ramdani, 2015) \& (Fahmi, Ramdani, Sunan, \& Djati, 2010).

\section{PROGRAMS \& INTERVENTION DESIGNS}

To determine the proper design to be given to the subject, analyzing the problem and its urgency is the first thing that the designers of the intervention program must do (Jackson, 2015). The study is based on the discovery and identification of problems concerning hypertension that can occur due to physical, psychological, and sociocultural factors of the individual. The goal is that when this intervention is given it is hoped that a better awareness and knowledge of the individual will arise from the various symptoms and situations they experience. Since the target of the early intervention program is the subject of a particular community, the intervention program to be undertaken is a community-based intervention program.

This community-based intervention program is very effective especially when subjects or targets to be subjected to this treatment are in a large community, so the designer needs a design that is classical for all subjects in a particular area. This community-based intervention program has been widely implemented and provides significant results on improved patterns of individual behavior change (Torlasco et al., 2017). In addition there is also a positive change of the subject when given a systematic and procedural intervention as in the case of coronary heart disease (Nikrahan et al., 2016). The success of the program is also largely determined by how the intervention designers make the subject a positive target and only on the grounds of getting a significant change (patients center) (Balint et al., 2016).

(Table 3. Community-Based Hypertension Intervention Program by (Fincham \& Kashdan, 2000)

\begin{tabular}{|c|c|c|c|}
\hline \multicolumn{3}{|c|}{ Framework for Facilitating Potential Hypertension } \\
\hline $\begin{array}{c}\text { Intensity of } \\
\text { intervention }\end{array}$ & Individual & Group & Social Unit \\
\cline { 2 - 4 } & \multicolumn{3}{|c|}{ Breadth of Reach } \\
\hline Prevention & \multicolumn{3}{|c|}{ Hypertension Information Campaign } \\
\hline Universal & \multicolumn{2}{|c|}{ Psychoeducation } \\
\hline Selective & \multicolumn{3}{|c|}{ Psychoeducation with hypertension implementation } \\
\hline Indicated & \multicolumn{3}{|c|}{ Psychoeduaction with relationship skills training } \\
\hline Enhancement & \multicolumn{3}{|c|}{ Hypertension-focused therapeutic intervention } \\
\hline Remediation & \multicolumn{2}{|c|}{. } \\
\hline
\end{tabular}

The hypertension intervention program to be undertaken is based on the framework conveyed by experts on the logic or flow of thinking in the community-based intervention as in the chart above. The type of intervention to be used is the Hypertension Information Campaign (HIC) at the universal level. HIC is an information campaign to promote awareness about hypertension and what should be and is not there. This program uses mass media useful in conveying information to the public (Fincham \& Kashdan, 2000). Using newspapers, posters, billboards, information pamphlets, and television. The instruments of the mass media must comply with the procedure steps appropriate to the quality of intervention and health research, ie effectiveness, appropriateness, and feasibility (Bn \& Ns, 2003). 
(Table 4. Intervention Design Specification)

\begin{tabular}{|c|c|c|c|c|}
\hline No & Form of Treatment & Procedure & Intensity & Challenges \\
\hline 1 & $\begin{array}{c}\text { Brochures } \\
\text { Is a sheet of } \\
\text { information through } \\
\text { HVS-sized paper that } \\
\text { is designed and } \\
\text { contains interesting } \\
\text { information about the } \\
\text { potential of } \\
\text { hypertension in } \\
\text { individuals }\end{array}$ & $\begin{array}{l}\text { Brochures are distributed to the } \\
\text { target community in two ways. } \\
\text { The first is by giving the } \\
\text { brochure sheet when the subject } \\
\text { has received the video } \\
\text { presentation treatment. } \\
\text { Second is by put the brochures } \\
\text { in places that are crowded and } \\
\text { can be taken anytime by } \\
\text { individuals who want to read it. }\end{array}$ & $\begin{array}{l}\text { a. Given every time } \\
\text { the subjects have } \\
\text { been watching } \\
\text { impressions about } \\
\text { hypertension } \\
\text { b. For brochures that } \\
\text { are put in public } \\
\text { places, the provision } \\
\text { is done twice a week } \\
\text { with different } \\
\text { information content. }\end{array}$ & $\begin{array}{l}\text { Because the shape is a } \\
\text { sheet can be tucked or } \\
\text { left behind. The content } \\
\text { should be so detailed } \\
\text { that the subject is really } \\
\text { interested in reading it. }\end{array}$ \\
\hline 2 & $\begin{array}{c}\text { Poster } \\
\text { Is a medium of } \\
\text { information in the } \\
\text { form of images and } \\
\text { short posts that are } \\
\text { made in a larger size } \\
\text { of A3 is usually } \\
\text { displayed in a place } \\
\text { that is easily } \\
\text { accessible and } \\
\text { viewed directly by the } \\
\text { target individual. }\end{array}$ & $\begin{array}{l}\text { The poster is made as attractive } \\
\text { as possible and corresponds } \\
\text { with the material on the } \\
\text { appropriate hypertension. } \\
\text { The poster will be affixed to the } \\
\text { building wall where the target } \\
\text { subject interacts with each other. } \\
\text { Place of attachment is a } \\
\text { classroom lobby wall, in the } \\
\text { classroom, mosque building, and } \\
\text { exit toilets. }\end{array}$ & $\begin{array}{l}\text { The poster is affixed } \\
\text { for a period of at } \\
\text { least two weeks to a } \\
\text { month. }\end{array}$ & $\begin{array}{l}\text { The poster should be in a } \\
\text { form that is clearly visible } \\
\text { and interesting. } \\
\text { Placement should be in } \\
\text { places where the subject } \\
\text { concerned can be very } \\
\text { frequent. } \\
\text { The message to be } \\
\text { delivered in the poster } \\
\text { should be } \\
\text { comprehensive as more } \\
\text { space is available. }\end{array}$ \\
\hline 3 & $\begin{array}{c}\text { Video } \\
\text { Media delivery of } \\
\text { messages through } \\
\text { actors or agents } \\
\text { delivered through } \\
\text { motion, examples of } \\
\text { communication, } \\
\text { media roles by } \\
\text { individuals who are } \\
\text { popular or have } \\
\text { certain authority } \\
\text { usually in the form of } \\
\text { video. }\end{array}$ & $\begin{array}{l}\text { The video is obtained from the } \\
\text { Special Unit of the Directorate of } \\
\text { Non-Communicable Disease } \\
\text { Control (DPPTM) of the Ministry } \\
\text { of Health which contained } \\
\text { material on hypertension. } \\
\text { Videos are created with } \\
\text { attractive designs and displays } \\
\text { and are a reference for } \\
\text { facilitators who want to develop } \\
\text { community-based interventions } \\
\text { like this. The video will be shown } \\
\text { to subjects approximately } 10 \\
\text { minutes before they perform the } \\
\text { lecture activity }\end{array}$ & $\begin{array}{l}\text { This video is given } \\
\text { approximately once a } \\
\text { week to the subject } \\
\text { to remind that the } \\
\text { government has also } \\
\text { been aware of this } \\
\text { case of hypertension. }\end{array}$ & $\begin{array}{l}\text { The seriousness and } \\
\text { concentration of subjects } \\
\text { on video viewing will be } \\
\text { considered. } \\
\text { The quality of the video } \\
\text { provided, the volume of } \\
\text { sound issued, and the } \\
\text { environmental conditions } \\
\text { in which the video will be } \\
\text { presented. }\end{array}$ \\
\hline 4 & $\begin{array}{c}\text { Public Message } \\
\text { It is a short message } \\
\text { containing information } \\
\text { about hypertension } \\
\text { that will be received } \\
\text { by individuals through } \\
\text { an active social media } \\
\text { account and } \\
\text { messages that go } \\
\text { directly to a private } \\
\text { number or with } \\
\text { messages posted on } \\
\text { the group that the } \\
\text { individual is a } \\
\text { member of. }\end{array}$ & $\begin{array}{l}\text { What is meant by public } \\
\text { messages is the media or } \\
\text { subject accounts in social media } \\
\text { where the intervention can be } \\
\text { given directly. } \\
\text { In this case will be done on } 3 \\
\text { media, namely Facebook, } \\
\text { WhatsApp, and telegram. These } \\
\text { three media are the most } \\
\text { popular media and often used } \\
\text { subjects during lectures and of } \\
\text { course for personal affairs. } \\
\text { Especially those posted in the } \\
\text { group they follow. } \\
\text { By using the media above, the } \\
\text { subjects will receive messages } \\
\text { and posts related to } \\
\text { hypertension and the programs } \\
\text { they can use. }\end{array}$ & $\begin{array}{l}\text { Giving this treatment } \\
\text { will be the most } \\
\text { intense, because } \\
\text { most easily and } \\
\text { efficiently. } \\
\text { For a week the } \\
\text { subjects will receive } \\
\text { messages and } \\
\text { messages from the } \\
\text { three accounts each } \\
\text { day. } \\
\text { The content will vary } \\
\text { and be sent at a time } \\
\text { when subjects are } \\
\text { expected to be } \\
\text { enthusiastic about } \\
\text { the information they } \\
\text { receive. }\end{array}$ & $\begin{array}{l}\text { Because that is used is a } \\
\text { technology-based media, } \\
\text { then the consideration is } \\
\text { the quality of the internet } \\
\text { both sender and receiver. } \\
\text { The time and conditions } \\
\text { expected to be accurate } \\
\text { and effective are } \\
\text { accepted by the subjects. } \\
\text { Enthusiastic subjects to } \\
\text { the message delivered. } \\
\text { So it is expected the } \\
\text { messages are given } \\
\text { repeatedly and intensely, } \\
\text { the sensitivity of the } \\
\text { subject to the content will } \\
\text { be greater. }\end{array}$ \\
\hline
\end{tabular}




\section{ACKNOWLEDGEMENT}

Many thanks to Indonesia Endowment Fund for Education (LPDP), Ministry of Finance - Republic of Indonesia who has provided support and sponsorship so that I can get a chance to enroll in the postgraduate program of psychology at UGM.

\section{REFERENCE LIST}

Balint, E. M., D, M., Boseva, P., Schury, K., Guendel, H., D, M., ... D, M. (2016). High prevalence of posttraumatic stress in patients with primary hypertension,. General Hospital Psychiatry, 38, 53-58. https://doi.org/10.1016/j.genhosppsych.2015.10.002

Bn, D. E., \& Ns, M. (2003). Hierarchy of evidence : a framework for ranking evidence evaluating healthcare interventions, 5005, 77-84.

Bozorgmanesh, M., Ghoreishian, H., Mohebi, R., Azizi, F., \& Hadaegh, F. (2014). Sex-specific predictors of the progression : community-based cohort of a West-Asian population. https://doi.org/10.1177/2047487313481757

Canada, H., Assessment, R., Mcbrien, K., Butalia, S., Zarnke, K. B., Mcfarlane, P. A., ... Hegele, R. A. (2017). Hypertension Canada's 2017 Guidelines for Diagnosis, Risk Assessment, Prevention, and Treatment of Hypertension in Adults. Canadian Journal of Cardiology, (February). https://doi.org/10.1016/j.cjca.2017.03.005

Cheng, H., Montgomery, S., Treglown, L., \& Furnham, A. (2016). Emotional stability, conscientiousness , and self-reported hypertension in adulthood. PAID. https://doi.org/10.1016/j.paid.2016.02.034

Fahmi, I., Ramdani, Z., Sunan, U. I. N., \& Djati, G. (2010). Profil kekuatan karakter dan kebajikan pada mahasiswa berprestasi.

Fincham, F. D., \& Kashdan, T. B. (2000). Chapter to appear in P. A. Linley \& S. Joseph (Eds.), 1-21.

Garner, R. E., \& Levallois, P. (2017). Associations between cadmium levels in blood and urine, blood pressure and hypertension among Canadian adults. Environmental Research, 155(February), 64-72. https://doi.org/10.1016/j.envres.2017.01.040

Grimshaw, J., Campbell, M., Eccles, M., \& Steen, N. (2000). Experimental and quasi-experimental designs for evaluating guideline implementation strategies, 17.

Gudmundsdottir, H., Høieggen, A., Stenehjem, A., Waldum, B., \& Os, I. (2012). Hypertension in women: latest findings and clinical implications, 137-146. https://doi.org/10.1177/2040622312438935

Jackson, W. (2015). Designing Projects and Project Evaluations Using The Logical Framework Approach The Logical Framework Approach, (December).

Kementrian Kesehatan. (2013). RISET KESEHATAN DASAR.

Kesehatan, K. (2015). Ringkasan Eksekutif Data dan Informasi Kesehatan Provinsi Daerah Istimewa Yogyakarta.

Leventhal, H. (2006). Psychological approaches to the connection of health and behaviour, 36(4), 666-682.

Martinovic, M., Belojevic, G., Evans, G. W., Kavaric, N., \& Asanin, B. (2017). Hypertension and correlates among Montenegrin schoolchildren $d$ a cross-sectional study. Public Health, 147(8), 15-19. https://doi.org/10.1016/j.puhe.2017.02.007

Nikrahan, G. R., Ph, D., Laferton, J. A. C., Ph, D., Asgari, K., Ph, D., ... Huffman, J. C. (2016). Original Research Reports Effects of Positive Psychology Interventions on Risk Biomarkers in Coronary Patients: A Randomized, Wait-List Controlled Pilot Trial. Psychosomatics, 57(4), 359-368. https://doi.org/10.1016/j.psym.2016.02.007

Perez, A. (2011). Self-Management of Hypertension in Hispanic Adults. https://doi.org/10.1177/1054773811411582

Ramdani, Z. (2015). Perumusan dan Pengujian Skala Kesabaran Sebagai Bentuk Coping Strategy. Laporan Skripsi. 
Riffle, K. L., Ph, D., Yoho, J., Sams, J., \& Ph, D. (1989). Health-Promoting Behaviors , Perceived Social Support , and Self-Reported Health of Appalachian Elderly, 6(4), 204-211.

Santosa, S. (2015). Menguasai Statistik Parametrik: Konsep dan Aplikasi dengan SPSS (Edisi kesa). Jakarta: PT Elex Media Komputindo.

Terre, L. (2009). Advancing the Prevention and Control of Hypertension. https://doi.org/10.1177/1559827609343416.

Torlasco, C., Faini, A., Makil, E., Ferri, C., Borghi, C., Veglio, F., ... Parati, G. (2017). SC. International Journal of Cardiology. https://doi.org/10.1016/j.ijcard.2017.03.151

Williams, E. N., Hurley, K., Brien, K. O., Gregorio, A. D. E., \& Mary, S. (2003). SELF-AWARENESS AND MANAGEMENT STRATEGIES ( SAMS ) SCALES FOR THERAPISTS, 4O(4), 278-288.

https://doi.org/10.1037/0033-3204.40.4.278 